\title{
Employment Status of Women in Rural Punjab: Dwindling Trends
}

Jaskaran Singh $^{1 *}$ and Kamlesh Goyal ${ }^{2}$

${ }^{1}$ Department of Economics, Ramgarhia College, Phagwara, Dist. Kapurthala, Punjab, India

${ }^{2}$ Department of Economics, Punjabi University, Patiala, Punjab, India

*Corresponding author: jksgill.economics@gmail.com

\begin{abstract}
Considerable participation of women in socio-economic, political and cultural set-up of the society is the pre requisite for the development of an economy. It is the fact that the economies which used the growth of agricultural sector as a base for their development path towards industrial and service sector growth shifted their surplus labour from agricultural sector to these sectors. Punjab has a different story regarding rural female employment. After green revolution, the state recorded tremendous agricultural growth. But this achievement in agriculture did not contribute in terms of female participation in economic activities and even this remarkable growth upto 1980's in agriculture sector brought a sharp decline of female work participation in farm-sector. In the nineties when major economic reforms were introduced in Indian economy, the major sectoral shift was noticed in employment which in result brought a rapid shrink in the number of agricultural workers in the state. Census 2011 figures present a gloomy situation for the gender equality in work participation in Punjab. Punjab continued backward for providing equal employment opportunities for the women. High mechanisation of agriculture and low growth of a nonagriculture sector made the situation worse for women to get employment. It is high time for a gender sensitive employment generation strategy to secure the socioeconomic interests of females in the state.

\section{Highlights}

( The rising proportion of non-agricultural employment and declining share of agriculture in GSDP is a signal of structural shift of the Punjab economy. Consequently, the existence of high gender disparities in rural employment reflects marginalisation of women in the state. Proportion of female workforce in agriculture sector has declined in recent decades mainly due to changing cropping pattern towards food grain crops where a less number of female workers involve due to intensive mechanization.
\end{abstract}

Keywords: Punjab's Economy, Women Employment, Work Participation and Gender Gap

The socio-economic condition of women in the society is an indicator of its civilization. Economically well-off status of women ultimately determines their position in the social milieu. Consequently the sociocultural pattern of old age is also responsible for their current economic prosperity. Socio-economic status of women is a measure of development in all spheres in any society. And the socio-economic status also determines the position of women in the decision making process which further opens up the gate of political freedom for women. It may not fair if only well-being of the family is taken as the parameter of a woman's status living in the family.
Well recognition of women in any society depends on freedom to work and availability of opportunities to work. Prestige of woman in the West is far above from their counterparts the in East Asian countries dominated by religious fundamentalists, where even some of them have done well in the economic front. On the other hand, economists and sociologists do believe that working conditions of female workers generally have a tendency to change according to the development stage of the economy. Participation of female workers remains high in traditional society where the economy depends on the primary sector. As soon as the 


\section{CP Singh and Goyal}

economy moves from the traditional primary sector to the industrial sector, the rate of female work participation starts declining. This is attributed to the shift from family-based production to large-scale production in industrial units. In the initial stage of development women with low level of education when the economy starts to transform from the agricultural sector to non-agriculture sector, women face difficulties to find work and have inhibitions in working as manual labour in the non-agricultural sector. But with an increase in family income and improvement in the education level of females, more and more females start entering the labour force, especially into non-manual or service oriented jobs. That is why the participation of females in the labour force in comparison with the economic growth is supposed to be U-shaped (Goldin, 1994; Qureshi, 2016).

Punjab is a northern state of India and known as predominately agrarian economy because the state experienced extraordinary growth of agricultural production due to use of new agricultural technology in the mid-sixties. Punjab led the country towards 'Green Revolution' and became the "Food Basket of India'. The people of Punjab are known for their hard work, farming skills and entrepreneurial spirit. Being predominantly agrarian state, big strata of the population depends upon the agricultural sector for earning their livelihood. In fact, agricultural sector influences the socio-economic profile of the whole state. But recent liberalization and market oriented policies are leading to the growth of non-agricultural sector very rapidly. Up-to the mid- nineties agriculture was the mainstay of the economy and the lifeline of the people of the state but after that agricultural growth remained consistently stagnant. Even though the Punjab economy is facing some direct challenges right now because of prevailing agricultural crises which is largely attributable to the mismatch of cost of cultivation and farm incomes. Under these circumstances, employment structure of economy of Punjab is needed to be focused. The economy of the state shifting from agriculture to non-agriculture sectors as for employment opportunities are concerned, equal participation of women and men in all economic activities becomes very important in rural and urban area. Various studies showed that position of female employment in India is on transform phase, though the work participation rate was declining, particularly in rural areas after economic reform introduced in India (Bhalla, 2008; Chadha, 2001; Rajput, 2004; Sanghi, 2015) and a little improvement was noticed in the work participation rate of urban women. The women work participation rate in rural Punjab (14.3 percent) recorded a new low as Census 2011 figures which is a serious matter of concern.

\section{Objectives, Data Sources and Methodology}

Female employability in rural Punjab especially after the Green Revolution is an issue which remained widely ignored by the researchers. To fill this gap, the present study is based on the following objectives: (i) to analyse gender disparities in rural and urban employment in Punjab, (ii) to investigate recent trends in the sectoral composition of rural employment in the state and the position of the female workforce in the new employment opportunities. To measure the disparities, the gender gap was measured between proportions and differentials were calculated to estimate variation among employment categories in rural areas between male and female worker. To show intrastate disparities district level comparison of work participation rate was also analysed by using the coefficient of variation. Whole study is based on Census data (various issues) and $68^{\text {th }}$ round of NSSO has been used which was conducted in 2011-12 to apportion the total workers of Punjab as per Censes 2011 into various categories.

\section{Tracking Agrarian Shift}

The growth pattern of different sectors of economy gives a fair idea about the structural change in an economy. The sector-wise share of gross domestic product (GDP) of the country and gross state domestic product has been presented in the table 1. The table indicatives of the fact that the Indian economy as well as of Punjab economy have shown a shift from primary sector of the economy to tertiary or service sector bypassing the secondary sector since 1980-81. In 1980-81 the share of primary sector in India's GDP was 31.91 percent which declined to 13.94 percent in 2013-14 while that of the tertiary sector increased from 39.92 percent to 59.93 percent during this period. However, in case of Punjab, the share of agriculture sector has declined 
Table 1: Sector wise comparison in Gross Domestic Product (GDP) of India and Gross State Domestic Product (GSDP) of Punjab in percentage (At Constant Prices, 2004-05)

\begin{tabular}{ccccccccccc}
\hline & \multicolumn{2}{c}{$\mathbf{1 9 8 0 - 8 1}^{*}$} & \multicolumn{2}{c}{$\mathbf{1 9 9 0 - 9 1}$} & \multicolumn{2}{c}{$\mathbf{2 0 0 0 - 0 1}$} & \multicolumn{2}{c}{$\mathbf{2 0 1 0 - 1 1}$} & \multicolumn{2}{c}{ 2013-14 } \\
\cline { 2 - 11 } Sectors & India & Punjab & India & Punjab & India & Punjab & India & Punjab & India & Punjab \\
\hline Primary & 31.91 & 49.50 & 29.11 & 44.00 & 23.02 & 35.89 & 16.48 & 25.06 & 13.94 & 23.88 \\
Secondary & 28.17 & 18.47 & 26.57 & 23.82 & 26.00 & 22.98 & 26.11 & 29.77 & 26.13 & 30.70 \\
Tertiary & 39.92 & 32.03 & 44.31 & 32.18 & 50.98 & 41.13 & 57.42 & 45.17 & 59.93 & 45.35 \\
\hline Total & $\mathbf{1 0 0}$ & $\mathbf{1 0 0}$ & $\mathbf{1 0 0}$ & $\mathbf{1 0 0}$ & $\mathbf{1 0 0 0}$ & $\mathbf{1 0 0}$ & $\mathbf{1 0 0}$ & $\mathbf{1 0 0}$ & $\mathbf{1 0 0}$ & $\mathbf{1 0 0}$ \\
\hline
\end{tabular}

Source: Statistical Abstract of Punjab, various issues, ${ }^{*} 1980-81$ prices.

from 49.50 percent to 23.88 percent and that of the tertiary sector increased from 32.03 percent to 45.35 percent during the same time period. On the other hand, the share of secondary sector in the GDP of the country has remained stagnant (declined but less as compared to other sector) but in case of Punjab it increased from 18.47 percent to 30.70 percent. Declining share of primary sector combined with highly mechanisation of agriculture, led to push out the working force from the primary sector, the manufacturing sector is not growing well, and these pushed working force (particularly women) who haven't enough skills and ability to get meaningful employment in the emerging service sector (Singh, 2006; Goyal, 2017).

\section{Rate of Work Participation and Gender Disparities}

Female workers constitute a significant portion of total workforce but usually they do not have equal access to labour market in developing countries. However, the invisibility of women's work, domestic chores and other tasks, view the man as the primary bread earner and considers women as non-workers. Even women themselves tend to regard their labour as 'domestic responsibilities' and are, therefore, less likely to engage in remunerated work. Various surveys by National Sample Survey Organisation (NSSO) of India on 'Employment and Unemployment Situation in India' reveal that 90 percent of women who did not participate in workforce attributed "pressing need for domestic work" as the primary cause for their non- participation (Hirway and Jose, 2011). This unfairness toward women brings gender disparities in employment opportunities.

Work Participation Rate $=$ Total Worker $/$ Total Population $\times 100$
As far as Punjab is concerned, female work participation is dwindling over the period of time especially during last decade. Figures in Table 2 show that female work participation rate declined from 19.1 percent in 2001 to 13.9 percent in 2011 and it was quite low from all over India figure which stood 25.6 percent in 2001 and 25.5 percent in 2011. In the first decade of the economic reforms, women workers in Punjab recorded a significant positive change of 14.7 percent in female work participation rate. This may also due to change in the definition of employment categories especially in agricultural related activities. Even then during the recent decade (2001-2011) a decline recorded in female work participation rate about 5.2 percent. On the other hand, male work participation consistently persists at above 50 percent in Punjab and India level but gender gap remained higher in Punjab. In Punjab, the gender gap in work participation increased up to 6.8 percent during 2001-2011 after a huge decline of 15.3 percent during 1991-2001 but gender gap was sharper in urban areas. It shows high inequalities in work participation rate in the employment of Punjab. As compared to other major states of India, Punjab stood at $15^{\text {th }}$ number and it was $11^{\text {th }}$ in 2001. Table 3 shows that the states like Andhra Pradesh, Rajasthan and Madhya Pradesh were more than ten percent higher in female work participation rate.

Table 3 shows that the majority of the workers in the state reported to be engaged in the nonfarm activities (64.4 percent) and most of the female workers (70.93 percent ) get involved in these activities, whereas the proportion of male workers were working in non-farm activities (62.9 percent) was less from female workers. This shows that women workers in Punjab are more prone to non-agricultural employment and reluctant to agricultural activities or unable to find employment 
Table 2: Work Participation and Gender Gap in Rural Areas (in percentage)

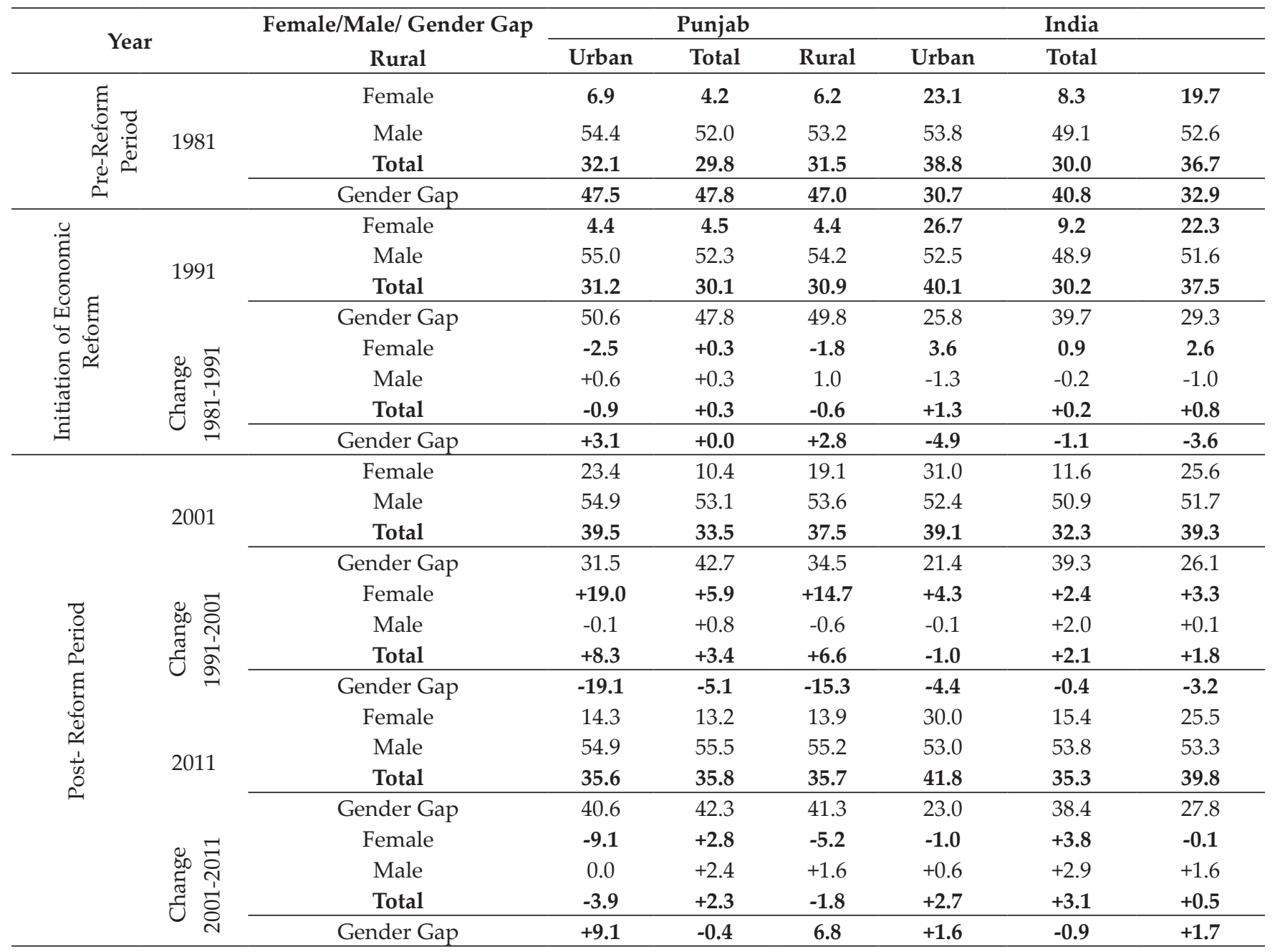

Source: Census of India, (Various Rounds).

in the rural agricultural base. The majority of the people used to reside in rural areas in the states and still most of them (53.64 percent) earn their livelihood from the agricultural sector (Sidhu and Singh, 2015). High mechanisation of agricultural operations adversely affected the labour force in general and women worker in particular due to under-developed non-agricultural sector to absorb work force released by the agriculture sector.

\section{Sectoral Composition of Rural Workforce}

On the other hand urbanised jobs mainly are supposed to be created with the development of industrial sector. But unfortunately due to a certain geographical position of far away from the seaport and being a border state, industrial base could not be established after successful implementation of 'Green Revolution' in the state. Some socio-cultural and personal factors may also be responsible for low women work participation rate in Punjab. Early upsurge in rural economy due to Green Revolution in the seventies and eighties break the family farming culture in agriculture and penetrated extensive mechanisation into the field. Women participation in farming activities started declining and they were replaced by firstly hired workers than implementing mechanization in Agriculture. Although in recent decade the share of agricultural females has grown up from one percent, 17.9 percent in 2001 to 19.1 percent in 2011. Reason behind this can be find in the tendency of increasing share of allied agricultural activities like dairy farming and livestock development. This sector accounts for lion's share in the composition of total agricultural income of the state. The sector like dairy farming in the state is supposed to be family and female labour intensive. Furthermore this sector is also a 
Table 3: State-wise Comparison of Female Work Participation Rate

\begin{tabular}{ccccc}
\hline States & $\mathbf{2 0 0 1}$ & Ranking 2001 & $\mathbf{2 0 1 1}$ & Ranking 2011 \\
\hline Punjab & $\mathbf{1 9 . 1}$ & $\mathbf{1 0}$ & $\mathbf{1 3 . 9}$ & $\mathbf{1 5}$ \\
Andhra Pradesh & 35.1 & 1 & 36.2 & $\mathbf{8}$ \\
Assam & 20.7 & 9 & 22.5 & 9 \\
Bihar & 18.8 & 11 & 19.1 & 7 \\
Gujarat & 27.9 & 6 & 23.4 & 13 \\
Haryana & 27.2 & 7 & 17.8 & 10 \\
Karnataka & 15.4 & 14 & 18.2 & 11 \\
Kerala & 15.4 & 15 & 18.2 & 3 \\
Madhya Pradesh & 33.2 & 3 & 32.6 & 5 \\
Maharashtra & 30.8 & 5 & 31.1 & 6 \\
Odisha & 24.7 & 8 & 27.2 & 2 \\
Rajasthan & 33.5 & 2 & 35.1 & 14 \\
Tamil Nadu & 31.5 & 4 & 31.8 & 14 \\
Uttar Pradesh & 16.5 & 13 & 16.7 & 18.1 \\
West Bengal & 18.3 & 12 & & \\
\hline
\end{tabular}

Source: Census of India, (Various Rounds).

Table 4: Sectoral Composition of Workforce in Punjab

\begin{tabular}{|c|c|c|c|c|c|c|c|c|c|}
\hline \multicolumn{5}{|c|}{ Farm-Employment } & \multicolumn{5}{|c|}{ Non-Farm Employment } \\
\hline Category & Year & Female & Male & Total & Category & Year & Female & Male & Total \\
\hline \multirow{4}{*}{ Cultivators } & 1981 & 5.9 & 37.0 & 35.9 & \multirow{4}{*}{$\begin{array}{l}\text { Workers in } \\
\text { Household } \\
\text { Industry }\end{array}$} & 1981 & 4.9 & 2.5 & 2.6 \\
\hline & 1991 & 8.7 & 32.5 & 31.4 & & 1991 & 3.2 & 1.3 & 1.3 \\
\hline & 2001 & 13.0 & 26.0 & 23.0 & & 2001 & 7.0 & 2.3 & 3.4 \\
\hline & 2011 & 9.9 & 21.7 & 19.6 & & 2011 & 7.5 & 3.1 & 3.9 \\
\hline \multirow{4}{*}{ Agri. Labourers } & 1981 & 25.3 & 22.1 & 22.2 & \multirow{4}{*}{ Other Workers } & 1981 & 64.0 & 38.5 & 39.4 \\
\hline & 1991 & 24.4 & 23.8 & 23.8 & & 1991 & 63.8 & 42.5 & 43.6 \\
\hline & 2001 & 17.9 & 15.9 & 16.4 & & 2001 & 62.0 & 35.8 & 57.3 \\
\hline & 2011 & 19.1 & 15.4 & 16.5 & & 2011 & 63.4 & 59.9 & 60.5 \\
\hline \multirow{4}{*}{ Total } & 1981 & 31.2 & 59.1 & 58.1 & \multirow{4}{*}{ Total } & 1981 & 68.9 & 41.0 & 42.0 \\
\hline & 1991 & 33.1 & 56.3 & 55.2 & & 1991 & 67.0 & 43.8 & 44.9 \\
\hline & 2001 & 30.9 & 41.9 & 39.4 & & 2001 & 69.0 & 38.1 & 60.7 \\
\hline & 2011 & 29.1 & 37.1 & 36.1 & & 2011 & 70.9 & 62.9 & 64.4 \\
\hline
\end{tabular}

Source: Census of India.

sub-sector for food processing industries needed to be installed in rural settings. At the same time, there has been dramatic widening of the gender wage differentials in the agriculture sector. Furthermore, in the agriculturally prosperous states where wages are relatively high, local male workers are being substituted by male migrant workers from poorer states (Singh, 2018).

This tendency ultimately affected the women workforce badly. Secondly, in the post economic reform era, cropping pattern of Punjab agriculture is more concentrated towards wheat-rice rotation pattern which requires less number of farm labourers. More than 80 percent cropped remained under the wheat-rice cropping pattern during the last decade. Area under vegetables, pulses, and cotton continued to decline at a rapid rate during the last 20 years and most of the rural female labourers get work when these crops are sown and harvested. Thus, this change in cropping pattern may also be responsible for the decline in the female workforce in Punjab especially in rural areas. This argument also looks strong because similar trends were noticed in neighbouring state Haryana where a sharp decrease was also observed in recent decade and the same wheat-rice oriented cropping pattern was being followed (Nisha, 2010).

\section{District-wise Variation in Employment}

Extent of work participation rate in rural and 
P) Singh and Goyal

Table 5: District wise Worker Participation Rate

\begin{tabular}{|c|c|c|c|c|c|}
\hline Districts & Rural/Urban/Total & Male & Female & Total & Gender Gap \\
\hline \multirow{3}{*}{ Amritsar } & Rural & 54.8 & 16.5 & 36.6 & 38.3 \\
\hline & Urban & 56.6 & 14.8 & 37.1 & 41.8 \\
\hline & Total & 55.8 & 15.6 & 36.9 & 40.2 \\
\hline \multirow{3}{*}{ Barnala } & Rural & 56.3 & 11.4 & 35.2 & 44.9 \\
\hline & Urban & 55.8 & 10.9 & 35.0 & 44.9 \\
\hline & Total & 56.1 & 11.2 & 35.2 & 44.9 \\
\hline \multirow{3}{*}{ Bathinda } & Rural & 59.6 & 20.9 & 41.5 & 38.7 \\
\hline & Urban & 55.9 & 13.1 & 36.2 & 42.8 \\
\hline & Total & 58.3 & 18.1 & 39.6 & 40.1 \\
\hline \multirow{3}{*}{ Faridkot } & Rural & 57.1 & 12.8 & 36.1 & 44.3 \\
\hline & Urban & 55.8 & 12.2 & 35.5 & 43.7 \\
\hline & Total & 56.6 & 12.6 & 35.9 & 44.1 \\
\hline \multirow{3}{*}{ Fatehgarh Sahib } & Rural & 56.7 & 12.0 & 35.7 & 44.7 \\
\hline & Urban & 57.6 & 10.2 & 35.9 & 47.5 \\
\hline & Total & 57.0 & 11.5 & 35.8 & 45.5 \\
\hline \multirow{3}{*}{ Firozpur } & Rural & 55.9 & 18.8 & 38.3 & 37.1 \\
\hline & Urban & 55.0 & 11.0 & 34.5 & 43.9 \\
\hline & Total & 55.7 & 16.7 & 37.3 & 38.9 \\
\hline \multirow{3}{*}{ Gurdaspur } & Rural & 51.8 & 10.7 & 32.2 & 41.1 \\
\hline & Urban & 54.4 & 11.8 & 34.9 & 42.6 \\
\hline & Total & 52.6 & 11.0 & 32.9 & 41.6 \\
\hline \multirow{3}{*}{ Hoshiarpur } & Rural & 50.4 & 10.6 & 30.8 & 39.9 \\
\hline & Urban & 53.0 & 13.8 & 34.2 & 39.2 \\
\hline & Total & 51.0 & 11.2 & 31.5 & 39.8 \\
\hline \multirow{3}{*}{ Jalandhar } & Rural & 55.2 & 11.6 & 33.9 & 43.6 \\
\hline & Urban & 56.4 & 14.1 & 36.6 & 42.4 \\
\hline & Total & 55.8 & 12.9 & 35.3 & 43.0 \\
\hline \multirow{3}{*}{ Kapurthala } & Rural & 54.8 & 11.6 & 34.0 & 43.3 \\
\hline & Urban & 56.0 & 14.3 & 36.5 & 41.7 \\
\hline & Total & 55.3 & 12.5 & 34.9 & 42.8 \\
\hline \multirow{3}{*}{ Ludhiana } & Rural & 55.8 & 16.3 & 37.1 & 39.6 \\
\hline & Urban & 56.8 & 12.7 & 36.4 & 44.1 \\
\hline & Total & 56.4 & 14.2 & 36.7 & 42.2 \\
\hline \multirow{3}{*}{ Mansa } & Rural & 57.0 & 30.5 & 44.6 & 26.6 \\
\hline & Urban & 54.3 & 14.6 & 35.6 & 39.6 \\
\hline & Total & 56.5 & 27.1 & 42.7 & 29.4 \\
\hline \multirow{3}{*}{ Moga } & Rural & 55.4 & 13.7 & 35.7 & 41.8 \\
\hline & Urban & 56.1 & 16.0 & 37.2 & 40.1 \\
\hline & Total & 55.6 & 14.2 & 36.1 & 41.4 \\
\hline \multirow{3}{*}{ Muktsar } & Rural & 58.1 & 16.1 & 38.2 & 42.0 \\
\hline & Urban & 55.3 & 11.0 & 34.5 & 44.3 \\
\hline & Total & 57.3 & 14.7 & 37.2 & 42.6 \\
\hline \multirow{3}{*}{ Patiala } & Rural & 55.1 & 10.8 & 34.2 & 44.3 \\
\hline & Urban & 54.4 & 14.8 & 35.8 & 39.7 \\
\hline & Total & 54.8 & 12.4 & 34.8 & 42.4 \\
\hline \multirow{3}{*}{ Rupnagar } & Rural & 52.5 & 15.2 & 34.7 & 37.3 \\
\hline & Urban & 51.6 & 11.6 & 32.6 & 40.0 \\
\hline & Total & 52.3 & 14.3 & 34.1 & 38.0 \\
\hline \multirow{3}{*}{$\begin{array}{c}\text { Sahibzada Ajit } \\
\text { Singh Nagar }\end{array}$} & Rural & 54.4 & 14.6 & 35.9 & 39.8 \\
\hline & Urban & 52.8 & 16.4 & 35.7 & 36.4 \\
\hline & Total & 53.5 & 15.6 & 35.8 & 37.9 \\
\hline
\end{tabular}




\begin{tabular}{cccccc} 
& Rural & 55.6 & 11.2 & 34.8 & 44.4 \\
Sangrur & Urban & 54.4 & 9.7 & 33.4 & 44.7 \\
& Total & 55.3 & 10.8 & 34.4 & 44.5 \\
Shahid Bhagat & Rural & 54.5 & 11.5 & 33.4 & 43.0 \\
Singh Nagar & Urban & 53.6 & 11.0 & 33.1 & 42.6 \\
& Total & 54.3 & 11.4 & 33.4 & 42.9 \\
& Rural & 53.3 & 12.9 & 34.1 & 40.4 \\
Tarn Taran & Urban & 52.6 & 11.0 & 33.0 & 40.6 \\
& Total & 53.2 & 12.6 & 34.0 & 40.6 \\
Punjab & Rural & 54.9 & 14.3 & 35.6 & 42.3 \\
& Urban & 55.5 & 13.2 & 35.8 & 10.3 \\
& Total & 55.2 & 13.9 & 35.7 & 6.0 \\
C.V.* & Rural & 3.8 & 32.8 & 8.7 & 8.6 \\
\hline
\end{tabular}

Source: Census of India, 2011. * Coefficient of variation.

urban areas at district level shows the economic inclusiveness in all over the state. When inferences are made to gender-wise within the districts, it depicts a broader picture of inclusiveness or disparities for work possibilities for women.

Table 5 represents a district wise picture of work participation rate in Punjab in 2011. It is clear from the values of coefficient of variation that in rural areas pattern of employment was more varied as compared to urban areas. Value of coefficient of variation of work participation rate of total rural workers stands at 8.7 percent that is doubled from the value for urban areas (3.9 percent). While in the case of work participation rate of female workers, value of coefficient of variation (32.8 percent) is ten times more than their counterpart male workers' work participation rate. This reveals that women not only participating less than men in economic activities in Punjab but the participation rate is also largely varied across the district of the state. District level data show that rural workers work participation is more strenuous in the cotton ballet of Punjab and districts fall in this area Bathinda, Muktsar, Mansa and Firozpur reported higher work participation rate especially in rural areas. For female work participation rate surprisingly Mansa and Bathinda districts reported highest women work participation rates 30.5 percent and 20.9 percent respectively across districts. In male work participation rate, not as such variation was found because the value of coefficient of variation is 3.3 percent only, but variation in rural work force participation rate was also high for male workers (Kaur, 2012).

\section{Inequalities in the Structure of Rural Employment}

From the above discussion, it was found that the work participation rate was drastically declined in recent decade and condition of women workers became worse after economic reform as for work participation rate is concerned. Traditionally the major sections of the rural population in Punjab, which were directly associated with two sectors (i) agriculture and allied agricultural activities and (ii) traditional shop keeper, artisans such as carpenters, blacksmiths, masons, potters, weavers and persons belonging to traditional service castes. Both of the sectors were dominated by male workers and the role of women was meagre as main worker in any rural activity, but they were engaged as helpers with their male counterparts. Besides this there were others such as small traders and self-employed and persons, including small shopkeepers owners of eating places, etc. who could be counted amongst those employed in the non-agricultural sector, such as owner of bicycle and other vehicle repair shops, electricians, plumbers and those involved in fabrication of agricultural implements.

Over a period of time second section has declined in numbers as also in terms of the time spend on traditional tasks in the working year. There is a salaried middle class section in the villages. These can be salaried persons in the state such as teachers, doctors, engineers and persons in police and other security forces as also quasi-government employees. There are also persons working in the non-state salaried jobs both in the private organized as well 
P) Singh and Goyal

Table 6: Numbers of Employed Persons according to Sectoral Divisions in Rural Punjab

\begin{tabular}{|c|c|c|c|c|c|}
\hline Divisions & Names & Male & Female & Total & $\begin{array}{l}\text { Differentials } \\
\%\left(\mathrm{~F} / \mathbf{M}^{*} 100\right)\end{array}$ \\
\hline \multirow{3}{*}{ (a) } & \multirow{3}{*}{ Agriculture \& Allied Activities } & 2815803 & 498930 & 3314733 & \multirow{3}{*}{74.80} \\
\hline & & $(56.36)$ & $(42.16)$ & $(53.64)$ & \\
\hline & & 2180017 & 684450 & 2864468 & \\
\hline (b) & Total Non-Agricultural Activities & $(43.64)$ & $(57.84)$ & $(46.36)$ & 132.55 \\
\hline \multicolumn{6}{|c|}{ Divisions of Categories of Non-Agricultural Activities (Sum of b1 to b18 Categories) } \\
\hline & & 437935 & 297829 & 735764 & \\
\hline b1 & Manufacturing & $(8.77)$ & $(25.17)$ & $(11.91)$ & 287.10 \\
\hline & Electricity, gas, steam and air & 50204 & 0 & 50204 & \\
\hline b2 & conditioning supply & $(1.00)$ & $(0.00)$ & $(0.81)$ & 0.00 \\
\hline \multirow{3}{*}{ b3 } & \multirow{3}{*}{$\begin{array}{l}\text { Water supply; sewerage, waste } \\
\text { management and remediation } \\
\text { activities }\end{array}$} & 6565 & 5010 & 11575 & \multirow{3}{*}{322.18} \\
\hline & & $(0.13)$ & $(0.42)$ & $(0.19)$ & \\
\hline & & 851924 & 24494 & 876418 & \\
\hline $\mathrm{b} 4$ & Construction & $(17.05)$ & $(2.07)$ & $(14.18)$ & \multirow[t]{2}{*}{12.14} \\
\hline \multirow{3}{*}{ b5 } & \multirow{3}{*}{$\begin{array}{l}\text { Wholesale and Retail trade; Repair } \\
\text { of motor vehicles and motorcycles }\end{array}$} & 271488 & 46484 & 317972 & \\
\hline & & $(5.43)$ & (3.93) & $(5.15)$ & \multirow[t]{2}{*}{72.28} \\
\hline & & 190004 & 835 & 190839 & \\
\hline \multirow[t]{2}{*}{ b6 } & Transportation and Storage & $(3.80)$ & $(0.07)$ & $(3.09)$ & \multirow[t]{2}{*}{1.85} \\
\hline & Accommodation and Food service & 14675 & 1113 & 15788 & \\
\hline \multirow[t]{2}{*}{ b7 } & activities & $(0.29)$ & $(0.09)$ & $(0.26)$ & \multirow[t]{2}{*}{32.02} \\
\hline & & 13130 & 0 & 13130 & \\
\hline \multirow[t]{2}{*}{ b8 } & Information and Communication & $(0.26)$ & $(0.00)$ & $(0.21)$ & \multirow[t]{2}{*}{0.00} \\
\hline & & 35143 & 2505 & 37648 & \\
\hline \multirow[t]{2}{*}{ b9 } & Financial and Insurance activities & $(0.70)$ & $(0.21)$ & $(0.61)$ & \multirow[t]{2}{*}{30.09} \\
\hline & & 2704 & 0 & 2704 & \\
\hline \multirow[t]{2}{*}{ b10 } & Real estate activities & $(0.05)$ & $(0.00)$ & $(0.04)$ & \multirow[t]{2}{*}{0.00} \\
\hline & Professional, Scientific and & 13516 & 0 & 13516 & \\
\hline \multirow[t]{2}{*}{ b11 } & Technical activities & $(0.27)$ & $(0.00)$ & $(0.22)$ & \multirow[t]{2}{*}{0.00} \\
\hline & Administrative and Support & 10813 & 0 & 10813 & \\
\hline \multirow[t]{2}{*}{ b12 } & service activities & $(0.22)$ & $(0.00)$ & $(0.17)$ & 0.00 \\
\hline & Public administration and Defence; & 55611 & 1670 & 57281 & \\
\hline b13 & Compulsory Social Security & $(1.11)$ & $(0.14)$ & $(0.93)$ & 12.68 \\
\hline & & 55225 & 124420 & 179645 & \\
\hline b14 & Education & $(1.11)$ & $(10.51)$ & $(2.91)$ & 951.13 \\
\hline & Human Health and Social work & 33212 & 18650 & 51862 & \\
\hline b15 & activities & $(0.66)$ & $(1.58)$ & $(0.84)$ & 237.06 \\
\hline & & 4634 & 0 & 4634 & \\
\hline b16 & Arts, Entertainment and Recreation & 0.09 & 0.00 & 0.08 & 0.00 \\
\hline & & 125510 & 149471 & 274981 & \\
\hline b17 & Other Service activities & $(2.51)$ & $(12.63)$ & $(4.45)$ & 502.76 \\
\hline & Activities of Households as & 7723 & 11969 & 19692 & \\
\hline b18 & employers. (Domestic Services) & $(0.15)$ & $(1.01)$ & $(0.32)$ & 654.24 \\
\hline & & 4995819 & 1183380 & 6179201 & \\
\hline & Total Employment $(a+b)$ & $(100)$ & $(100)$ & $(100)$ & \\
\hline
\end{tabular}

Figures in parentheses are percentage to Total Employment $(a+b)$, Source: NSSO 68th round and Census of India, 2011 
as unorganized sectors including personal services such as maids, cooks, personal security guards and derivers, gate keepers, etc. Thus, non-agricultural activities in rural areas are quite a heterogeneous lot consisting of a very large number of different activities ranging from domestic servants employed by richer rural households on the one extreme and capitalist entrepreneur to the other (Anupama, 2007).

The NSS employment/unemployment survey categories the large number of heterogeneous rural non-agricultural activities industry groups such as manufacturing, construction, trade and repair other services, transport, storage and communication, education, public administration and social security and social and personal services etc. Data from 68th round of NSS has been used which was conducted in 2011 to apportion the total rural workers of Punjab as per Censes 2011 into various categories. The role of women in other rural non-agricultural activities is very significant when the diversification of the whole rural economy is needed as a way out of the crises in Punjab economy. The results from table 5 show that share of the female workforce in education related activities are quite high as compared with that of males. There is totally male dominance in many non-agricultural activities such as mentioned as b2, b6, b7, b8, b9, b10, b11, b12, b13, and b16 in table 4 . Manufacturing and construction are other two categories in which women have significant work participation. The high value of differential (951.13 percent) in the category of education reveals that women were far above than men in rural areas and male workers' contribution in this field was quite low. The values of differential 74.80 percent and 132.55 percent in agriculture and total non-agricultural activities respectively indicate that women are still not equally participating in all existing activities in rural areas of Punjab. Thus there were high gender disparities when the participation of male and female in different occupations is concerned in rural Punjab.

\section{SUMMING UP}

To sum up, the rising proportion of non-agricultural employment and declining share of agriculture in SGDP is a signal of structural shift of the Punjab economy. Consequently, the existence of high gender disparities in rural employment reflects marginalisation of women in the state. Proportion of female workforce in agriculture sector has declined in recent decades mainly due to changing cropping pattern towards food grain crops where a less number of female workers involve due to intensive mechanisation. A considerable participation of females in manufacturing, construction and other service sector activities is noticed. This reveals that women are capable enough to adjust themselves in all emerging non-agricultural activities. Trends show that existing cropping pattern does not allow them to participate in large numbers, they supposed to be oriented towards allied agricultural activities like dairy and animal husbandry but how many of them continue to be observed in these activities, depends upon the potentials of these vary activities. Public and private Initiatives towards education, health, and other service sectors in the rural areas can provide them the employment opportunities of their interests. Skill development centres should be established at village level with equal opportunities available to the women. Many studies show that there is a positive relationship between level of education and female work participation rate. Variety in higher education is needed for rural women in the state so that they can adjust themselves to the changing requirements of all available non-farm activities. The agricultural sector is also needed to be strengthened by providing due importance to diversified allied activities like dairying in it where the female workforce can be absorbed for some extent. Undoubtingly rural industrialisation is the need of the hour and agro food processing industries may also be a viable option for rural areas to create employment for females. Hence, it is the high time for a gender sensitive employment generation strategy to secure the socioeconomic interests of females in the state.

\section{ACKNOWLEDGEMENTS}

This paper is the revised version of 'Employment Status of Women in Rural Punjab: The Post Reforms Scenario' presented by author at Kerala Institute of Local Administration (KILA), Thrissur, Kerala on 8 to 10 November, 2017. The author is thankful to Prof. H.S. Sidhu Consultant, Punjab State Farmers' and Farm Workers' Commission, Mohali for the constructive observations and extensive comments as well as suggestions on an earlier draft of this article. 
PD Singh and Goyal

\section{REFERENCES}

Anupama 2007. Gender Discrimination in Quality of Employment and Wages in Unorganised Manufacturing Sector of India. The Indian Journal of Labour Economics, 50(4):1007-1019.

Bhalla, G. S. 2008. Globalisation and Employment Trends in India. The Indian Journal of Labour Economics, 51(1).

Chadha, G.K. 2001. Impact of economic reforms on rural employment. Indian Journal of Agricultural Economics, 56(1):491-525.

Goldin, C. 1994. The U-shaped Female Labour Force Function in Economic Development and Economic History. Working Paper No. 4707. Cambridge, MA: National Bureau of Economic Research. Retrieved from http://www. nber.org/papers/ w4707.

Government of India. 1981. Census of India. New Delhi, Ministry of Home Affairs.

Government of India. 1991. Census of India. New Delhi, Ministry of Home Affairs.

Government of India. 2001. Census of India. New Delhi, Ministry of Home Affairs.

Government of India. 2011. Census of India. New Delhi, Ministry of Home Affairs.

Government of Punjab. 2015. Economic survey of Punjab 201415. Chandigarh.

Government of Punjab. 2015. Statistical abstract of Punjab 2014-15. Chandigarh

Government of Punjab. 2016. Economic survey of Punjab 201516. Chandigarh.

Goyal, K. 2017. Structural Change and Growth of Manufacturing Industries in Punjab: A Post-reforms Analysis. 21 $1^{\text {st }}$ Annual Conference of the Indian Political Economy Association on the theme of Inclusive and Sustainable Development: Theoretical and Empirical Perspectives, IIT Delhi, India
Hirway, I. and Jose, S. 2011. Understanding women's work using time-use statistics: The case of India. Feminist Economics, 17(4).

Kaur, P. and Kaur, G. 2012. Factors Affecting Female Labour Force Participation in Punjab: An inter-district analysis. Journal of Research in Peace, Gender and Development, 2(4): 81-88.

Nisha, S. and Ravi, S. 2010. Women, Work, and Employment Outcomes in Rural India. Economic and Political Weekly, 45(28): 49-63.

NSSO 2014. Employment and Unemployment in India. 20112012, NSS $68^{\text {th }}$ Round, 2012 (Report No. 554). New Delhi: Ministry of Statistics and Programme Implementation, Government of India.

Qureshi, M.A., Khan, P.A. and Uprit, S. 2016. Empowerment of Rural Women through Agriculture and Dairy Sectors in India. Economic Affairs, 61(1): 75-79.

Rajput, P. 2004. A Situational Analysis of Women in Punjab. National Commission for Women, New Delhi.

Sanghi, S. S. A. and Vijay, S. S. 2015. Decline in Rural Female Labour Force Participation in India: A Relook into the Causes. Vikalpa-The Journal for Decision Makers, 40(3): 255-268.

Sidhu, H.S. and Singh, J. 2015. Promoting Rural Non-Farm Employment Through Skill Development in Punjab, Punjab State Farmers' Commission, Mohali, Punjab.

Singh, B. 2006. Decline in Agricultural Employment and Adjustment Through Labour Commuting: A Case Study from Punjab. The Indian Journal of Labour Economics, 49(4): 863-869.

Singh, R. 2018. Empower the Farmer: Make Sure Women Farmers Don't Get the Short End of the Stick. Economic Times, January 29, 2018. 